\title{
SETTLEMENT OF NON-PERFORMING LOAN THROUGH MEDIATION AT BANK OF CENTRAL ASIA CO., LTD. OF BENGKULU BRANCH OFFICE
}

\author{
By: \\ Tara Maziyyah, Edytiawarman, Widya N. Rosari
}

\begin{abstract}
This study aims to determine and analyze the settlement of problem loans through the mediation of PT. Bank Central Asia Bengkulu Branch and to identify and explain the obstacles that arise in the settlement of non-performing loans at PT. Bank Central Asia, Bengkulu Branch. The research method used is empirical legal research, the research location was at PT Bank Central Asia Bengkulu Branch Office, the data collection technique was carried out through interviews. In PT Bank Central Asia, Bengkulu Branch, there are 178 people who are debtors. If the debtor does not fulfill his obligations, there will be default, which can cause the credit activity to become a non-performing loan. The settlement of non-performing loans at PT Bank Central Asia, the bank first carries out the negotiation stage, if the obligations are still not fulfilled by the debtor, the next step is to carry out the mediation process. The process of settling nonperforming loans through mediation at PT Bank Central Asia Bengkulu Branch is carried out by means of internal mediation, which is the mediator, namely from the Legal and Compliance Task Force team at the Sentul Head Office, Bogor. There are 7 debtors who have completed problem loans until the mediation stage. The non-performing loan settlement process has never been carried out by means of litigation and never through OJK. Inhibiting factors have 2 causes, namely from internal factors and external factors. The suggestion for this research is to provide insights about the mediation process to the debtor so that the debtor understands the mediation process.
\end{abstract}

Keywords: Non Performing Loans, PT Bank Central Asia, Mediation 


\section{A. INTRODUCTION}

\section{Research Background}

The term credit is already familiar to society in general, and in the banking environment in particular. The definition of credit according to Article 1 number 11 of Law Number 10 of 1998 concerning Banking is:

"Credit is the provision of money or an equivalent claim, based on a loan agreement or agreement, to pay off the debt after a certain period of time with interest." Credit that is given by the bank to the debtor based on an agreement must be in accordance with the terms of the agreement in the Civil Code. In addition, credit is the delivery of a certain amount of money based on a lending and borrowing agreement. Article 1338 paragraph (1) of the Civil Code states that all agreements made legally are valid as laws for those who make them.

Banks as fund distributors and credit fund providers for the community do not always run smoothly, there are times when debtors do not fulfill their obligations according to the agreed time (default). Default is considered as a failure to carry out an obligation without reasons that can be accepted by law. To deal with bad credit, there are various efforts made by the Bank to return money belonging to depositing customers, either through regular credit collection or through other means. The recovery process carried out by the Bank is very difficult because in general the debtors faced are debtors who are bankrupt, have bad intentions, have passed away, and even the debtors have run away (skip). To deal with this, the Bank usually uses the parate executie auction mechanism.

In this case, as a financial institution, Bank of Central Asia Co., Ltd issues credit products offered to consumers or customers as debtors. Credit facilities offered by Bank of Central Asia Co., Ltd with a total of 6 types of credit facilities were:

1. Home Ownership Credit

2. Apartment Ownership Credit

3. KPR Xtra (Home Ownership Credit - Extra)

4. BCA Refinancing of Home Ownership Credit

5. Motor Vehicle Credit

6. Motorcycle Credit 
Mediation is one of the alternative forms of suspect settlement including being able to resolve nonperforming loans. Banking mediation is a dispute resolution process that involves a mediator to assist the disputing parties to reach a settlement in the form of a voluntary agreement on some or all of the disputed issues. Regulations concerning mediation are regulated in Bank of Indonesia Regulation No. 10/10/PBI/2008. Based on pre-research at Bank of Central Asia Co., Ltd. of Bengkulu branch office, one example of a case that occurred was a debtor / customer of Bank of Central Asia Co., Ltd. of Bengkulu branch office in 2014 which has a loan or credit of Rp. 500,000,000, - (Five hundred million rupiah) with a credit period of four years and collateral in the form of land and buildings, not the debtor's property but the right of the guarantor (in this case the debtor's parents). In the current period of one year, the payment made by the debtor was still fairly smooth, but after entering the second year the installment payments started to stall.

Rescue of non-performing loans by Bank of Central Asia Co., Ltd, namely: in the first stage the Bank calls the customer through the first warning letter. If the first summons are ignored, the bank will call back by issuing a second summons. In this case the Bank of Central Asia Co., Ltd comes to the debtor's place of business to ask about the obstacles that the debtor is facing. Based on the results of the debtor's survey, the business experienced a very drastic decline. After conducting a survey from Bank of Central Asia Co., Ltd, the action taken was to summon the debtor to settle the non-performing loan. However, the debtor never has the good intention to settle the problem loans that the debtor was facing.

So far, banking practices in resolving disputes have not used the non-litigation process much. This can be seen from the agreements made between banks and customers that do not include clauses such as arbitration, mediation and so on, as stated in POJK No. 1 / POJK.07 / 2014 concerning Alternative Dispute Resolution Agencies. Settlement of disputes, whether through court or arbitration is formal, compelling, 
looking at the problem behind it by paying attention to the nature of the conflict and what the rights are based on. In this case, the parties who resolve a dispute must go through a case termination procedure which is based on strict provisions and the legal rights and obligations of the parties. Conversely, alternative dispute resolution is informal, voluntary, forward-looking, cooperative and based on interests.

\section{Identification of problems}

Based on the background description above, the issues raised in this research is as follows:

1. How to solve problem loans through banking mediation at Bank of Central Asia Co., Ltd of Bengkulu branch office?

2. What are the inhibiting factors in the settlement of problem loans through banking mediation at Bank of Central Asia Co., Ltd of Bengkulu branch office?

\section{B. RESEARCH METHODS}

The type of research used is empirical legal research. In empirical legal research, law is conceptualized as an empirical phenomenon that can be observed in real life; in this case the law was not merely conceptualized as an independent (autonomous) normative phenomenon, as ius constituendum and ius costitum, but empirically ius operatum, namely law as what is in society. ${ }^{1}$ Therefore, this empirical legal research is classified as legal effectiveness research which was a legal research which aims to examine the effectiveness of a statutory regulation.

\section{RESULTS AND DISCUSSION}

\section{Settlement of Non-Performing}

\section{Loans through Banking Mediation}

at Bank of Central Asia Co., Ltd of

Bengkulu Branch Office

Loans that need special attention are performing loans that have weaknesses and if it was not repaired, this can result in a decrease in the ability of the debtor to fulfill his obligations on time. These types of loans must be included in the collectability in special attention (TPF) in accordance with applicable regulations, and require special attention from management to immediately determine corrective actions so as not to become a Non-

\footnotetext{
${ }^{1}$ Burhan Bungin, Pokok-Pokok Metode Hukum Empiris Murni, Trisakti University Publisher, Jakarta, 2009, p. 24
} 
Performing Loan (NPL). As for data from several customers who have become debtors since 2015-2020, the payment constraints experienced by Bank of Central Asia Co., Ltd (BCA), namely:

\begin{tabular}{|c|c|c|c|}
\hline No. & Name & Ceiling & $\begin{array}{c}\text { Reasons for Loss of } \\
\text { Payment and Settlement }\end{array}$ \\
\hline 1. & Samsudin & IDR $150,000,000$ & $\begin{array}{l}\text { Additional loss from a side } \\
\text { business. The types of } \\
\text { business are open } \\
\text { photocopies and boarding } \\
\text { houses. After the debtor's } \\
\text { mediation process sold the } \\
\text { assets under construction } \\
\text { himself, in March } 2020 \text { the } \\
\text { problem was resolved }\end{array}$ \\
\hline 2. & Yadi & IDR $750,000,000$ & $\begin{array}{l}\text { Businesses close and quit } \\
\text { insurance employees, based } \\
\text { on the results of the } \\
\text { settlement mediation carried } \\
\text { out in May } 2020 \text {, namely take } \\
\text { over to other banks that } \\
\text { people bought. }\end{array}$ \\
\hline 3. & Maman Emansyah & Rp. 300,000,000 & $\begin{array}{l}\text { Bad debt in January } 2020 \\
\text { (SP3), then conducts an } \\
\text { auction until it was purchased } \\
\text { by a third party. }\end{array}$ \\
\hline 4. & Kurnia & IDR 450,000,000 & $\begin{array}{lll}\text { Bad debt in } & \text { August } & 2020 \\
(S P 3) \text { then sold } & \text { other } \\
\text { personal assets } & & \\
\end{array}$ \\
\hline 5. & Darma & Rp. $800,000,000$ & $\begin{array}{l}\text { The business is closed, then } \\
\text { the settlement was carried out } \\
\text { by auction }\end{array}$ \\
\hline
\end{tabular}

This was confirmed by the account officer of PT Bank Central Asia Bengkulu who stated that: ${ }^{2}$ "The late payments faced by these customers occurred due to the impact

2 The results of an interview with the Account Officer of PT Bank Central Asia (BCA) Bengkulu, namely Bram Sanjaya, on September $3^{\text {rd }}$ of 2020 at 16.00 WIB. of Covid-19 on the business they are running. Therefore, for this reason, the payment process, which is usually smooth every month due to the Covid19 , it was hampered even in arrears of payments and finally the collateral was auctioned by the bank.

One of the ways to deal with 
non-performing loans is to deal with the non-performing loans mentioned above, by means of mediation. Debtors also take mediation steps through third parties in resolving problem loans so that they can be resolved quickly.

The settlement efforts made by the BCA of Bengkulu Branch in the case of bad credit either caused by bad trade receivables, force majeure, only then if the restructuring was deemed unsuccessful will the settlement of credit be carried out amicably by selling collateral under hand, and the last is to settle credit through legal channels carried out by the KPKNL (State Assets and Auction Service Office).

Based on the results of an interview with Mr. Bram Sanjaya stated that: ${ }^{3}$

"The mediation carried out at Bank BCA is through the assistance of the Legal and Compliance Unit at the $B C A$ Head Office, namely the BCA Learning Institute Sentul, Bogor as a third party assisting. The mediation process is carried out through video converence, because the distance does not allow face-toface mediation. . So far, PT Bank BCA Bengkulu has always resolved its problems through non-litigation channels and never made it to court"

One of the ways to deal with non-performing loans is to deal with the non-performing loans mentioned above, by means of mediation. Debtors also take mediation steps through third parties in resolving problem loans so that they can be resolved quickly.

Debt settlement is an effort to settle non-performing loans by banks against debtors whose business has no prospects or no longer has a business, or has bad faith therefore their debt cannot be restructured. There is a debt settlement made by $B C A$, which is as follows:

a. Consultation

Consultation conducted by problem debtors to PT Bank Central Asia is an attitude or an action that shows there is still good faith from the debtor in resolving the problems that occur. This stage is usually the 
debtor tells the cause of the late payment which made the credit problem. PT. BCA Bank will find the best solution for the debtor by offering 3R, namely, Rescheduling, Reconditioning (re-requirements), and Restructuring.

b. Negotiation

Negotiation is a good stage taken by debtors to immediately settle non-performing loans by making debt repayment offers to get repayment relief.

c. Mediation

The mediation step was also taken by debtors through third parties in settling debtproblem therefore it can be resolved quickly. If the mediation way is chosen by the parties, there are several elements in the mediation, namely the existence of a dispute between two or more parties, a willingness to resolve disputes through mediation, the presence of a mediator. However, in this case, the mediator only has to provide suggestions or not as the case with a judge or arbitrator, a mediator is not in a position (not having the authority) to decide the disputes of the parties. The mediator's duties and powers are only to assist and to facilitate the disputing parties to reach a situation to be able to agree on the matters in dispute. The scope of Mediation can only be implemented and be used as a method of resolving disputes outside the court (Out-of-court Settlement) for civil disputes arising between parties, and not in criminal cases or State Administration. Thus, any civil dispute in the banking sector (including those stipulated in PBI No.10/1/PBI/2008) can be submitted and to be resolved through the Banking Medication Institution. The Bank Indonesia Regulation concerning Banking Mediation provides that before being taken to a banking mediation institution, any dispute between a customer and a bank must be resolved internally by the bank concerned. If the settlement does not reach an agreement, the customer can bring the problem to the Bank 
Indonesia banking mediation institution.

d. Inhibiting Factors in the Settlement of Non-Performing Loans through Banking Mediation at PT Bank Central Asia of Bengkulu

The method of dispute settlement is through a negotiation process to obtain an agreement between the parties with the assistance of a mediator (Supreme Court Regulation Number 1 of 2008 concerning Mediation Procedures in Courts). Mediation has principles that are voluntary or subject to the agreement of the parties, in the civil field, simple, closed and confidential, and are mediating/facilitating in nature. In the mediation process, it is always mediated by one/more mediators who are chosen by the disputing parties, the selection of a mediator must be carried out carefully and with full consideration because a mediator will play an important role in resolving disputes that occur between the parties.
In the mediation process, a mediator has a role as the party that oversees the process of mediation, such as arranging negotiations, holding meetings, arranging discussions, being a mediator, formulating an agreement between the parties.

PT. Bank Central Asia of Bengkulu Branch will give reprimand or verbal warnings to debtors to carry out the main credit payment obligations in the form of credit installments, to improve their credit status. When it returns to normal, BCA will continue the installment payment process including interest.

If the warning doesn't get a result, then BCA will use the second stage, which is to provide a warning letter to the customer. The contents of the letter are in the form of:

1.Notification regarding debtpayment due

2. Total debtors' liabilities/debts that must be paid

3. Orders to pay liabilities/debts in accordance with the stated amount 
The deadline for debtors to make payments to $\mathrm{BCA}$ by the giving of warning letters by BCA three times in a row. If the debtor still does not have good intentions to fulfill his obligations, BCA will make efforts to save debt.

Efforts to save debt within BCA can be carried out by conducting negotiations and auctioning collateral. In terms of negotiations, BCA will recall the customer to negotiate a solution to ease the debtor's debt burden, which is expected to provide an opportunity to make debtpayments.

\section{CLOSING}

\section{Conclusion}

1) Non-performing loan settlement through banking mediation at Bank of Central Asia Co., Ltd of Bengkulu Branch, where $\mathrm{BCA}$ has never resolved problems through the court but a mediation process to safeguard bank secrecy.

2) Inhibiting factor of nonperforming loans settlement through banking mediation at Bank of Central Asia Co., Ltd of Bengkulu Branch, where in the process of settling non-performing loans, BCA banks often experience obstacles in the form of customers who are not consistent in resolving non-performing loans they are currently facing.

\section{Suggestion}

It is hoped that this thesis can be a reference for future writing regarding the settlement of non-performing loans.

\section{REFERENCES}

\section{Books}

Arus Akbar Silondae dan Andi Farian Fathoeddin, 2010,2013, Aspek Hukum Dalam Ekonomi dan Bisnis, Mitra Wacana Media, Jakarta.

Bambang Sutiyoso, 2008, Hukum Arbitase dan Alternatif Penyelesaian Sengketa, Gama Media, Yogyakarta.

Burhan Bungin, Pokok-Pokok Metode Penelitian Hukum Empiris Murni, Penerbit Universitas Trisakti, Jakarta, 2009.

H.Budi Untung, 2000, kredit perbankan di Indonesia, Yogyakarta. 


\section{Regulation}

Peraturan OJK No. 1/POJK.07/2013

Tentang Perlindungan Konsumen

Sektor Jasa Keuangan

\section{Peraturan Bank Indonesia \\ No.10/10/PBI/2008 Tentang Mediasi \\ Perbankan}

